\title{
ブラシ組織の電子顕微鏡観察
}

国分欣治**石川㑆二**

\section{Observation of Microstructures of Brushes by Electron Microscope}

\author{
by
}

K. Kokubu and K. Ishikawa

(Railway Technical Institute of J. N. R. Tokyo)

As 'we found equi-centred multi-ringed bodies on each sliding surface of pitch coke brushes under an electron microscope, we tried to trace them to the origin in each manufacturing process and clear up their characteristics. As a consequence, we could confirm that they originated from vortex-like bodies which had been generated in flow layers of coal pitch coke through the coking process, but not in petroleum pitch coke; that these microstructures were formed with equi-centred multi-shells which were composed of fine carbon crystals and ordinary graphite grains in turn, whose orientations of crystalits on each shell were apparently perpendicular. Besides, dropping out traces of shells were observed easily on each polishing and sliding surface of brushes. Considering these structures and the others, then, we could estimate them to be hard or stiff and have high electric resistance.

Trying to investigate how influential the multi-shelled body had been on electric sliding contacts, we could notice that it played a significant role in the brush ability; commutation, damages of a commutator and brush wear, and that variances in brush ability depended upon its distribution on the sliding surface.

\section{1.はしがき}

炭素ブラシは物理特性が同一であっても, 性能が異な ることはよく知られた事実である。これは物理特性がブ ラシ素材に関する性質をよく表示していないか, 性能を 表示する特性を欠いているためである。一般に物理特性 はブラシ素材に対する平均的な性質であるのに, ブラシ 性能は整流子またはスリップリングとのすり接触から派 生する現象により判定され, 接触面の状態, 材質特性, 雾囲気, 機器の特性と運転条件などから規定されるので, 単なる物理特性からブラシ性能を表示することは本来困 難な事柄である。すり接触の特徵は Holm ${ }^{(1)}$ p Rabino wicz ${ }^{(2)}$ らの研究から, 接触時の真実接触点の数や面積 は極めて小さいので, 接触面の凹凸や摩摖および電気特 泩に関係を持つ微細構造が大きな影響を与えることが明 白である。したがってブラシ材質の規定は一般物理特性 による反面, 特異的な微細構造面からもなされる必要が

* 炭素材料に関する第 18 回学術研究発表講演会発 表, 昭和 40 年 12 月 3 日 (東京)

** 鉄道技術研究所
ある。一方ブラシ性能のばらつきを物理特性面から究明 し得ないことは経験に徴しても明らかで, 接触面におけ る微細構造の不均一分布に求めざるを得ない点がある。 筆者はこれまですり接触の立場から，ブラシしゅう動が stick-slip 運動をとることや，火花によるブラシ摩耗 量の増加は粒子脱落摩耗であること, 通電に当ってはフ リッティング痕が発生するなど，ブラシの損傷を顕微鏡 観察 ${ }^{(3)}$ によって明らかにしてきた。今回ブラシ素材に関 する微細組織の研究が必要であることを痛感して, ピッ チュークス系ブラシにつき電子顕微鏡による検討を行な った。この方面の研究はこれまであまりなされていなか ったようである。その結果ブラシ素材中には径約数 $\mu$ の 同心円からなる多重環構造体がかなり認められ，これは 多重球殼構造をとって原料の石炭ピッチコークス中に内 在することが判明した。またこれがブラシ性能におよぼ す影響をすり接触特性面から検討して，この量および分 布の如何がブラシ性能に影響するところ大であることを 明らかにした。

\section{2. 試料および実験方法}


文宸素

試料は国鉄納入 5 社のピッチコークス系 D種ブラシを 使用したが，その特性值はTable 1 にしめす通りである。

Table 1 Physical properties of 'test brushes

Brands Apparent Specific Transver-Friction of Bru- Density Resistance se Strength Coefficishes $\quad \mathrm{g} / \mathrm{cm}^{3} \quad \mu \Omega-\mathrm{cm} \quad \mathrm{kg} / \mathrm{cm}^{2}$ ent $\mu$

$\begin{array}{lllll}\mathrm{A} & 1.75 & 1.160 & 290 & 0.25 \\ \mathrm{~B} & 1.67 & \mathbf{1 . 6 6 0} & 370 & 0.27 \\ \mathrm{C} & 1.71 & \mathbf{1 . 1 5 0} & 390 & 0.25 \\ \mathrm{D} & 1.65 & \mathbf{1 . 2 1 0} & 360 & 0.27 \\ \mathrm{E} & 1.65 & \mathbf{1 . 6 2 0} & 280 & 0.27\end{array}$

このブラシのすり接触面と素材研磨面を試料としたが， ブラシのすり面は温湿度自動調整付すり接触湘定器 ${ }^{(4)} に$ よって作成した。測定器の銅スリップリング洤は $160 \phi$, $600 \mathrm{rpm}$, ブラシ压力 $1.6 \mathrm{~kg}$, ブラシ寸法 $10 \times 16 \times 22$ $\mathrm{mm}$, 雾田気温度 $32 \sim 40^{\circ} \mathrm{C}$, 相対湿度 $15 \%$, ᄂ中 5 動時 間 50 h 以上で通電 (D.C. $20 \mathrm{~A} / 1.6 \mathrm{~cm}^{2}$ ), 無通電にわけ て実験した。

電子顕微鏡のレプリカはすり面をそのまま数回ビオデ ンで付着摩耗粉を除去した後に一般レプリカを作り，こ れにクロームとカーボンを約 45 度の方向から真空蒸着 するフィルミーレプリカ方式を採用した。ブラシ素地の 場合にはエメリ紙でよく研磨した後にアルミナでバフ研 磨を行ない，最後はアルコールによるバフ研磨仕上げを した後, 上記のようにレプリカ作成をした。測定は日本 電子製スーパスコープで行ない，直接倍率 1,000 2,000 倍を適宜引伸して観察したが 5,000 倍前後が多 w。

\section{3. 実験結果}

\section{1 ブラシすり接触面上の多重環}

Photo 1 は A 銘柄の槽内温度 $40^{\circ} \mathrm{C}$, 湿度 $15 \%, 600$ $\mathrm{rpm}, 20 \mathrm{~A} / 1.6 \mathrm{~cm}^{2}$, しゅ5動時間 $64 \mathrm{~h}$ で得られたも のであるが，このときのブラシ平均温度は $75^{\circ} \mathrm{C}$, リン゙ 温度は $66^{\circ} \mathrm{C}$ であった。Phote 1-(a) の中央上部に径 約 $4 \mu$ の同心円からなる三重環構造体と, その左肩に不 鮮明ながら小型の二重環が認められる。すり方は久印 のよらに斜上方に向かい，この痕跡条痕がかすかに喼め られる。素地の中には集団をなして屋根瓦状に配列した 結晶の突起が認められる。これはすり面とある傾斜方位 をとる黒鉛結晶の露頭とも言うべきもので，しゅう動に 伴なら衝突力を受けて結晶が䢃開したものと考えられる。 レプリカのシャドウはすり方向から行なっているのです り方向に近い力が蒸着物が多くなるので黑くなり, 反詨 側は影になるので色が薄くなる。小乫起の下方が黒くな

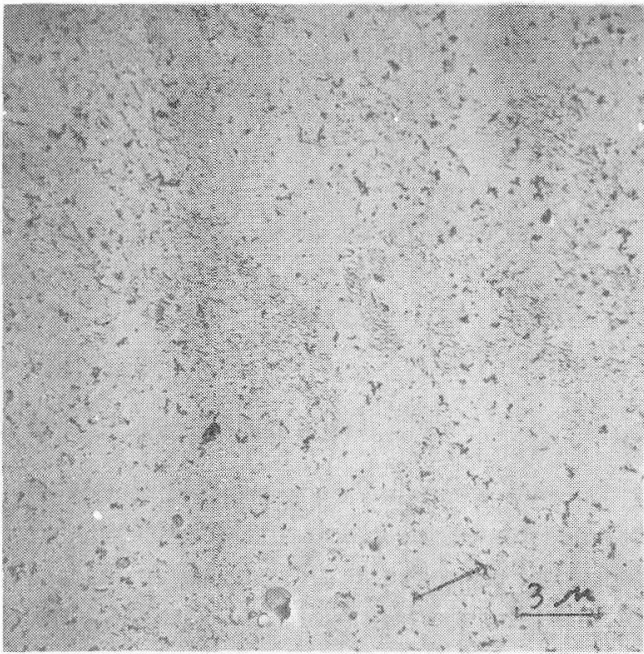

(a)

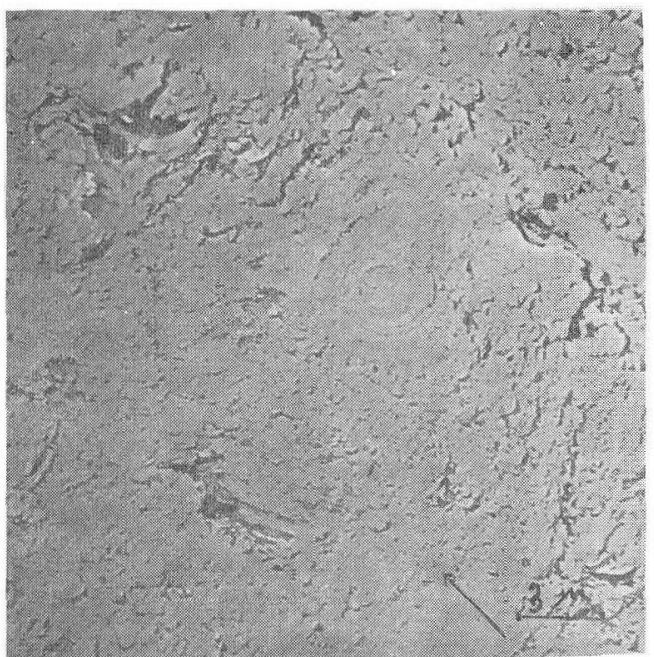

(b)

Photo 1 A sliding surface of brush brand A with current $20 \mathrm{~A} / 1.6 \mathrm{~cm}^{2}$

り上方が白色であるのはこのためである。黒色部の巾に 比較して白色部の力が広いので，この部分が䢃開面であ ると推定したのである。電子顕微鏡の倍率が高く，面の 研磨が上手に行なわれておれば，より鮮明な像が得られ るので䢃開面であるか否かの判定ができるであろうが, この写真からは推定の域をでない。Fulam ${ }^{(5)}$ らの文献 と対応させて考えれば譬開面とみる考え方の方が歩があ る。すなわち露頭結晶子の傾斜角がすり方向とある鋭角 值をとる場合に結晶の䢃開が起ると表現することができ る。このさい角度が小さ過ぎれば䢃開は起り難くなり, 
大き過ぎて直角に近くなれば投影図形が小さくなって写 真に捕え難くなる。またこの写真中に平滑面が諸所に認 められるが，これは結晶方位がすり面にほぼ平行してい る部分と考光た方がよい。䢃開面の発達した摩耗片が付 着配向して平滑部を形成することも考完られるが，一段 レプリカ作成時に数回空取りしたビオデン膜に摩耗粉の 付着が見られるからである。

Photo 1-(b) には径約 $5 \mu$ の四重環のほか，すり方 向にほぼ直角なクレバスようの黒い線や, 白黒が対にな った微少三角点が認められるが，これも上記同様傾斜方 位をとる結晶の露頭である。粒子脱落痕も認められる。

以上の点からブラシすり面は一見平滑に見えてもかな りの凹凸があり，その上多重環のよらな特異構造も存在 することが明らかになった。これまでピッチコークス系 ブラシに多重環棈造体が存在すると言ら報告例がないの で, 素材に予め存在するものか, 通電などすり接触によ って発生するか不明である。そこでまず無通電ブラシの すべり面を作成したが，その条件は槽内温度 $32^{\circ} \mathrm{C}$, 湿度 $15 \%$ ，ブラン玨力 $1.6 \mathrm{~kg} / \mathrm{cm}^{2}, 600 \mathrm{rpm}, 52 \mathrm{~h}$ Lゅ5 動後のブラシ平均温度 $54^{\circ} \mathrm{C}$, リング温度 $49^{\circ} \mathrm{C}$ であった。 Photo 2 はその一例であるが, Photo 1 に比較して 面の様相がかなり異っており，その傾向は 2-(b) に著 しい。2-(a)の中央には三重環が認められるほか，左 上には多重環の脱落痕と思われる同形の凹痕があり，右 下に法内環が脱落した多重環がある。これらの観察から 多重環は球款構造であって, 素地との結合力や同心殼層 間の結び付きも強固でないことが推定される。2-(b) では二重環構造が認められるほか，すり方向に直角なク レバスようの発達が見られるが，全体が熱腐食面のよう な外観を呈している。これは配向した結晶子面に見られ るピットと面の様相から推定したもので，無通電すり面 の特異面である。

Photo 3 に無通電すり面のパノラマ写真をあげたが, 写真左側には多重環の脱落痕, 右側には円形の凹痕とこ れを取り巻く火口壁のような斜面, 中央部には条根に直

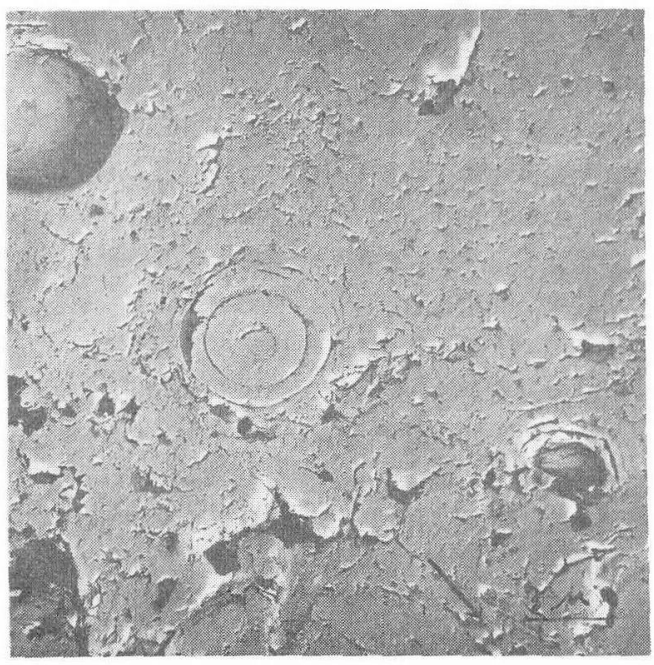

(a)

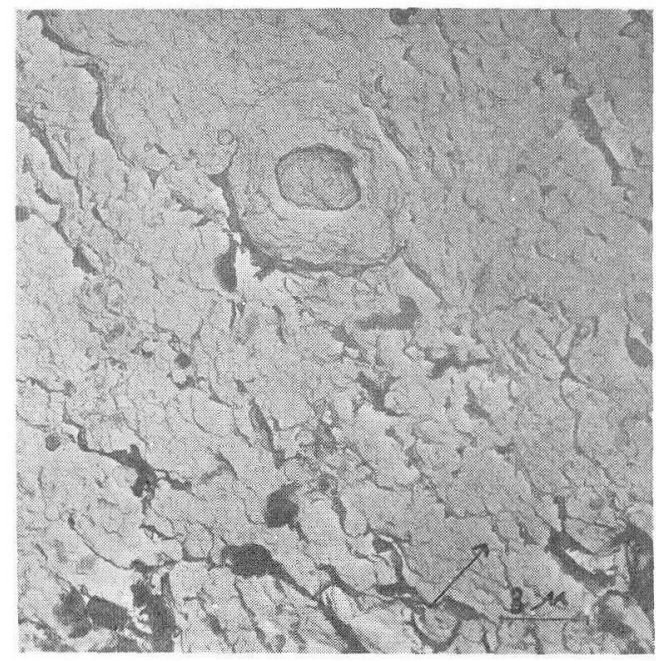

(b)

Photo 2 A sliding surface of brush brand A with no current

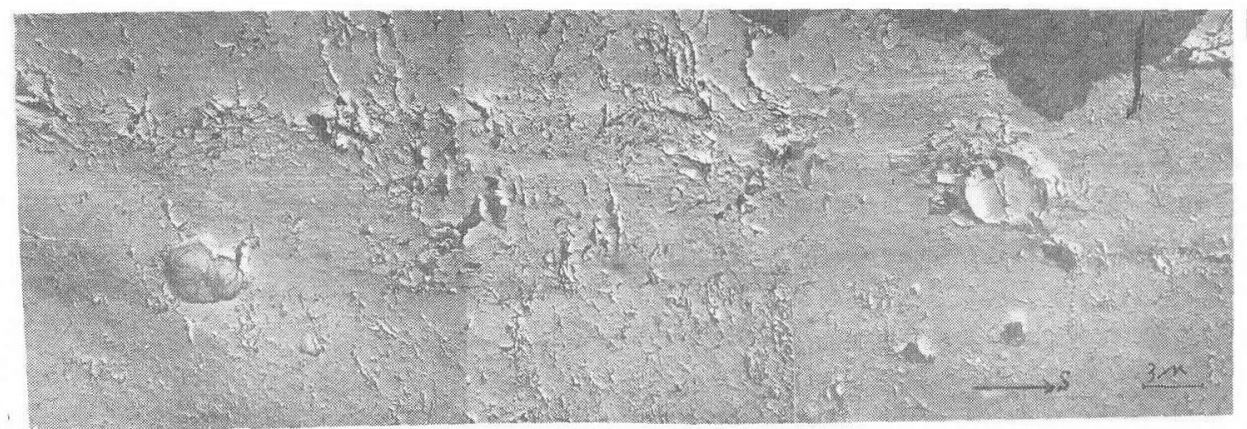

Photo 3 A sliding surfaces of brush brand A under no current 
角な突起が多数認められる。脱落凹痕面には結晶子に見 合う多数の平滑面が認められるが，これは多重環を取り 巻く素地の黑鉛結晶子の大きさや方位に対応するもので ある。また条痕をよく見ると条痕の濃淡や巾の広狭に気 付くほか, 中断または偏位する様相が判る。したがって 接触時の振動や接触点の移動, さらに衝突の様相などを 推定することができる。ブラシに対応するスリップリン グ側の寸り面の一例はPhoto 4 にあげる道りで, Stick-Slip 運動を物語るクラックがすり方向と直角に 成長しているのが判る。

以上のようにすり接触面の観察から, 多重環は通電の 有無に関係なくすり面上に見出される点を考虑すると， 通電すり接触から派生したものではなく, 素材に内在す る見透しが高くなった。

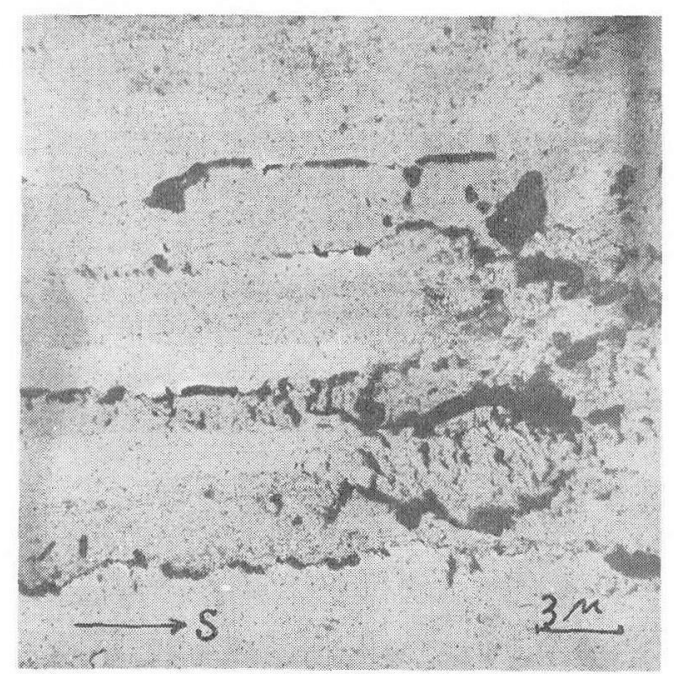

Photo 4 A sliding surface of slip ring

\section{2 ブラシ素材と多重環}

ブラシ素材中の多重環検討に当って, 摩耗粉の目ずま りを防ぐためにアルコールによるバフ研磨を実施した。 な抢試料は Table 1 の 5 銘柄であるが, 銘柄 B t除い て他の銘柄にはすべて多重環の存在が明らかにされた。 その代表例をあげるとPhoto 5 の通りである。5-(a) には 4 個の核を持つ複合環に 1 個の環が連結した連結複 合環が下部に認められる。この大きさは $21 \times 9 \mu$ を越光 るもので，粉砕工程を受けたにもかかわらず，その形が 保存されている点から環構造の剛性がかなりのものであ ることが推定される。また環を形成する黒鉛は微細型と 細粒型とが交互に繰返され, 前者は求心的な方位をとり 後者は円周方位型である。一方素地黑鉛との比較から環 構造体の低黑鉛化性が推定されるほか，上部の核脱落痕 跡の存在から素地との結合が比較的弱いことも推定され
る。あたかも鉄龬中の非金属介在物のように研磨の過程 またはすり接触中にPhoto 3 のように脱落する可能性 をしめしている。5-(b) は独立多重環であるが，5(c)共々微細黒鉛の心核のみからなる環の存在をもしめ している。これらの核の周囲には円周方位を持つ結晶子 が存在している所から, 環形成の少年期のものと推定さ れる。また5-(d) の下方に, 中心核がこれまでの敘細 型と異った結晶性のよい粒子から成り立つ多重環加認め られ，上方の環と対称的である。なお同心環の構造が雨 環ともに結晶性のよい粒子から成り立っているのも特徴 的である。多重環の多くは微細型であるがこのように結 晶度の高いものもあるので成因は色々あると予測される。 銘柄差は上記のように多重環の種類と環形成の発達度の 差異にあらわれるが，その分布と量のちがいも印象的で あらた。B銘柄の写真は割愛したが, 素地結晶子の発達 がよい上に, スートと思われる粒子集団が存在していた ことは，他銘柄と異る点であり印象的である。

以上の観察から多重環は $\mathrm{A}$ 銘柄のみでなく石炭ピッチ コークス系ブラシの共通特珄であって, 環の種類や量の 差は原料コークス自体の差にもとづくものと推定される。

\section{3 多重環の成因之特性}

ブラシ黒鉛化品に認められる多重環の成因を確かめる ために製造工程を遡上って追求した。A銘柄の一次焼成 品の組織はPhoto 6 に示寸通りで, 長大な複合連結環 が彎曲状態で認められるが，環の組織は目づまりのため に不鮮明である。素地の結晶は未発達な様相をしめすほ か, クラックが目立っている。

次いで成型品を検討したが，結合剂が研磿時に溶融し して面を覆らために多重環の存在は輪郭を推定し得るが, 確認には到らなかった。

さらに石炭ピッチコークスについて検討し, 代表例を Photo 7 にあげた。このちち(a), (b) は中ピッチ, (c) は高ピッチの縦断面組織である。多重環の存在は明 瞭に確認できるが，組織の詳細は目づまりのため不鮮明 である。多重環の周囲にはいずれもピッチュークス特有 な流れが認められるので, 環の生成はピッチがュークス 化するさいの流動過程において, 渦生成類似の機整によ り同心の多重環がある時間経過を経て形成されたものと 推定される。時間経過と流吵体の性質如何によっては, 各種の環が心核から連結複合環まで多㮔類に形成される ことが推定できる。またこのさい中心核となるものはピ ッチ中に先天的に存在する遊離炭素分が低級分子を絬合 剤として形成されるか，Photo 5 -(d) で指摘したよう に, 流動過程中に発達したゲル状の高分子成分が中心核 となる場合も考光られる。一般に渦の中心核には周柬流 体より密度の高いものがなる可能性が多いので, この場 


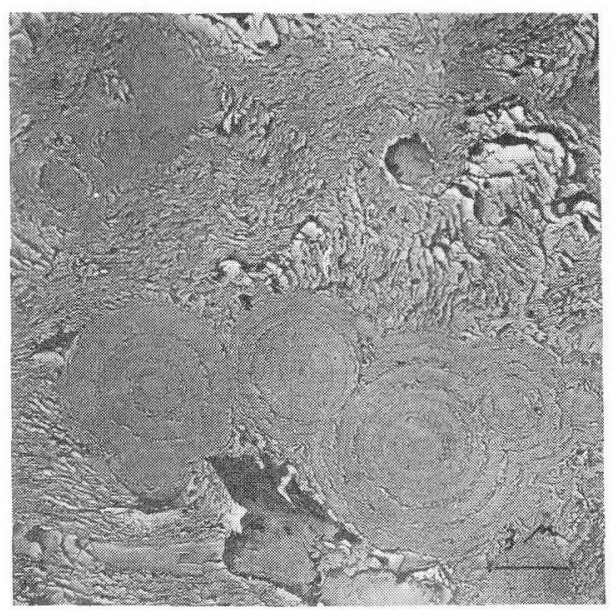

(a)

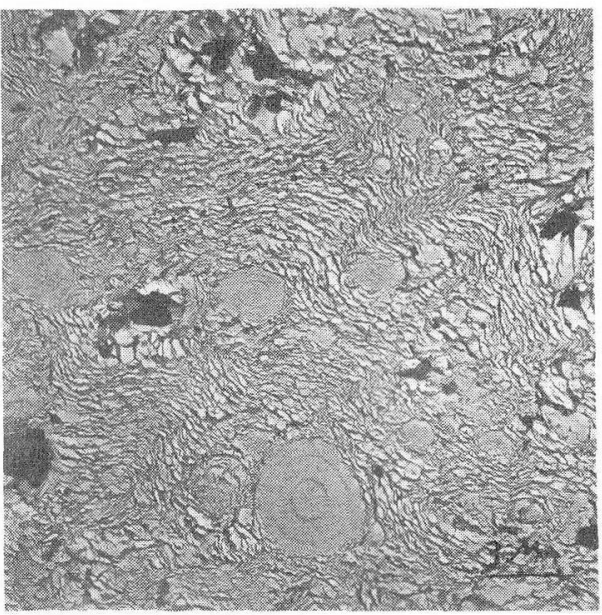

(b)

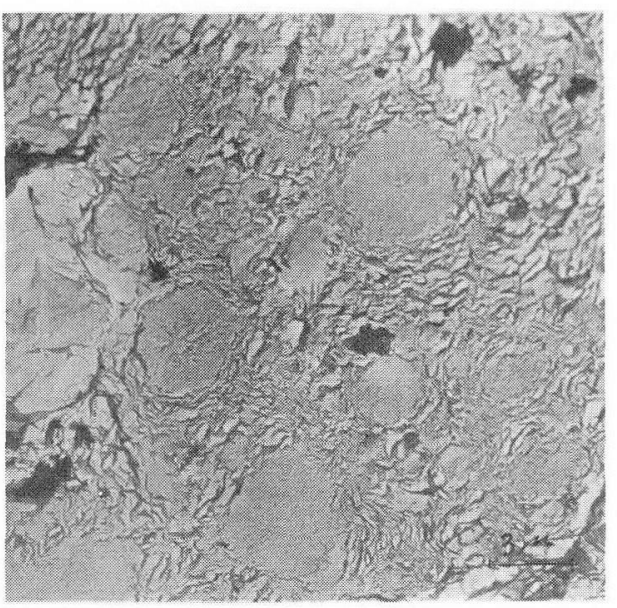

(c)

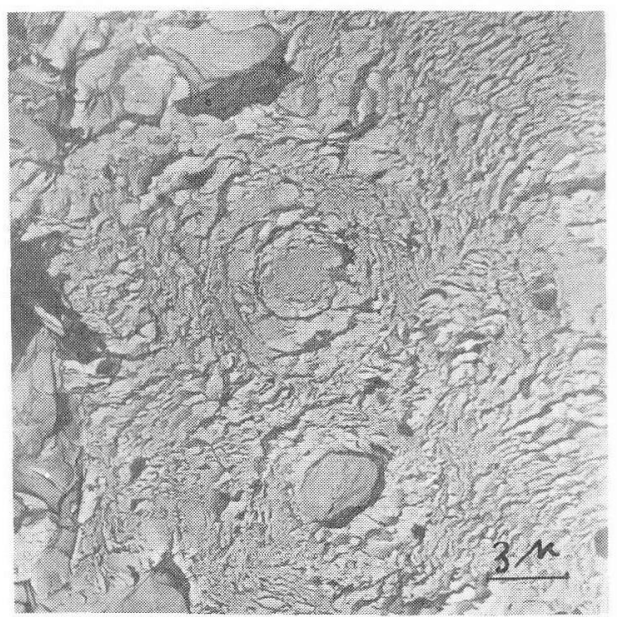

(d)

Phote 5 Examples of multi-ringed bodies

合も同様と考えられる。7-(a)の右上部には心核群が認 められ，独立環周囲の流れの粒子配位が環に垂直である 点が注目を引く。7-(c)左上部の二重環と7-(b)の多重 環とは様相が異るので，前者は中心核が結晶性のよい埋 鉛からなる5-(d)に対応するものと思われる。

同心環の構造については，これまでも触れてきたが， 求心方位環と円周方位環の交互繰返しが多い。このさい 前者の結晶子は微細且緻密であるが，後者のそれははる かに発達がよい。環の厚みは生成条件によって異るが， 求心方位環が厚い場合の例が多い。厚みの如何では 5(d)に見られるように円周方位環のみのような例もあれ ば，5-(b)のように求心方位環がほとんどと言った例も ある。しかし両者の合成によって形成されていると考え た方がよい観測例が多い上に，諨の脱落し易さを見ても

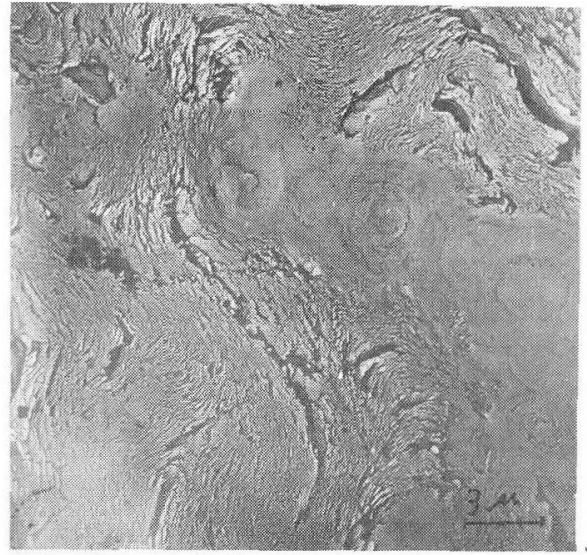

Photo 6 Primary heat treated structure of brush brand A 


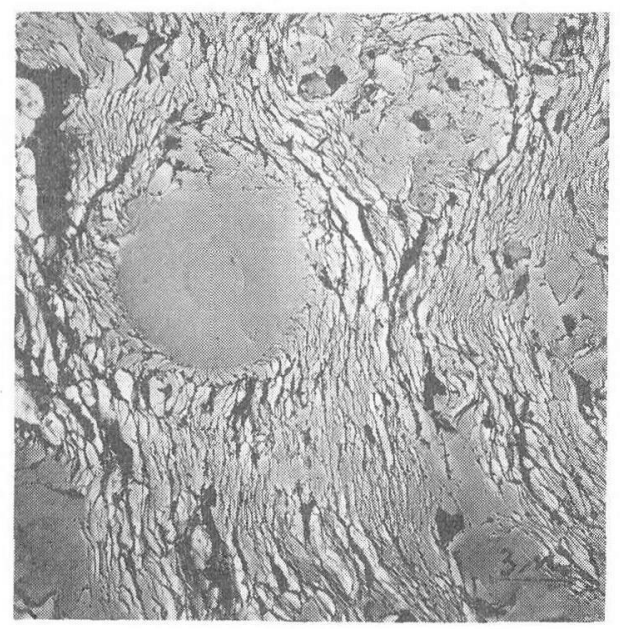

(a)

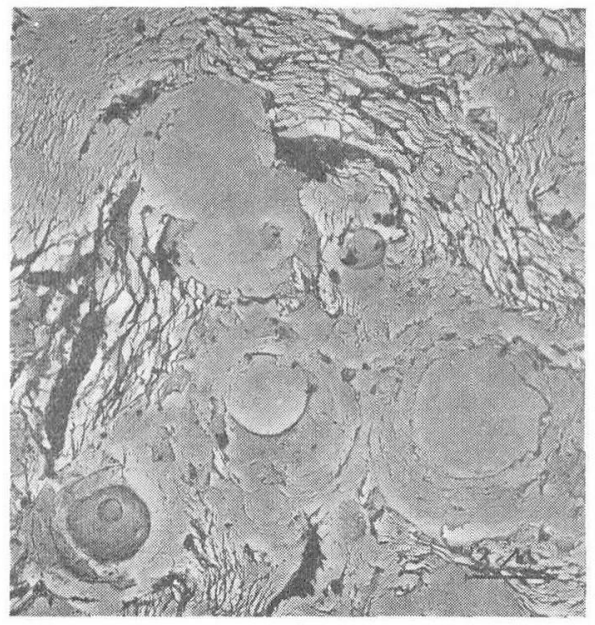

(b)

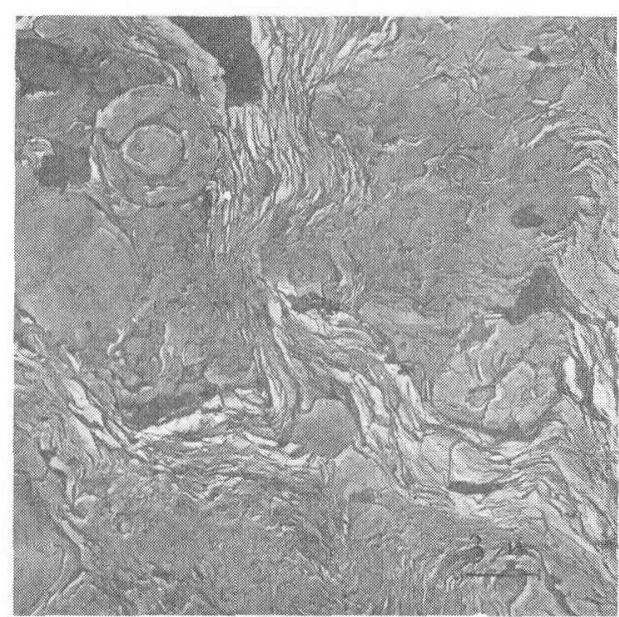

(c)

Photo 7 Microstructures of coal pitch coke

結合力が弱い点が明らかなので，合成構造と考える方が 合理的である。勿論厚さは周囲条件から決定される。

多重環の形状については, 切断面の直角断面をとって 検鏡しても，同心多重環しか見当らず，脱落痕の形状を 見ても球殼体であることを否定する資料はない。これら から多重球款体であると推定して誤はない。その寸法は 連結複合環のように長いものもあるし, Photo 8 のよ らにずんぐりした複合環もあって多様である。

多重環の特性についてはこれまで述べてきたように, 環形成の黒鉛は微細で黒鉛化度が低いと推定される上, 粉碎工程後でもその形状を保つ点などから硬質で䧐性に 富むと推定される。数百枚の電顕写真中から破碎環が得 られたのはPhoto 9 に見られるもので唯一の例である。 これのブラシ銘柄はDであった。また電気特性を考える

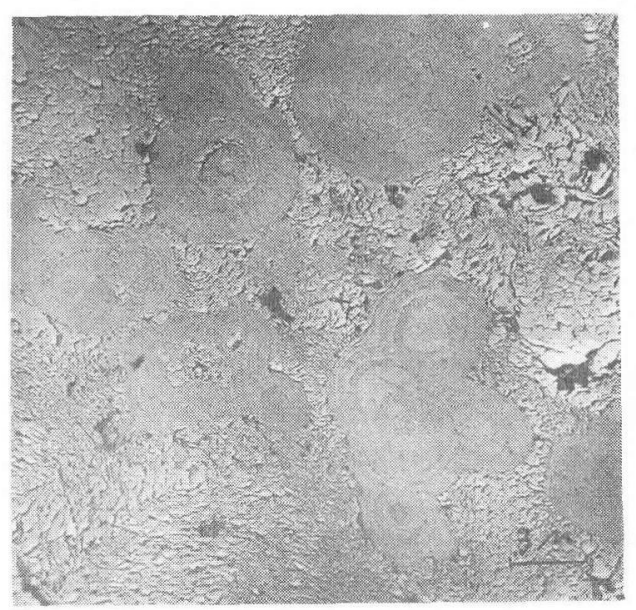

Photo 8 Multi-ring complexes 
と，一般的に微細組織で黒鉛化度が低いと予想される上 に，結晶方位が直交する同心環構造になっているので， 環体自身の電気抵抗が高いばかりでなく，素地との接触 抵抗もまた大きいと推定される。

多重環の分布について鉝属顥徽鏡を用いて石炭ピッチ コークスを检討した所Phote 10 が得られた。見られる 通りかなり多量の多重環がピッチコークス中に存在する ことが明らかである。また黒鉛化品や一次焼成品中の分 布も決して均一なものではなく銘柄差も存在する。

以上のように多重環は石炭ピッチコークスがコークス 化するさいの流動過程中に乱流に基づく渦成分類似の過 程を経て形成されると言う推定がなされたが，B銘柄の ように環の存在が認められないものもある。そこで石油 コークス (G.L.)を検討したが，Photo 11 に見る如

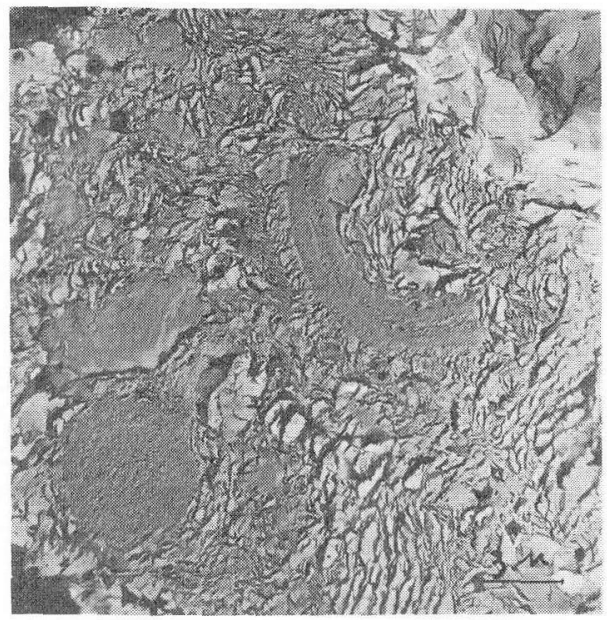

Photo 9 A Fragment of multi-ringed body

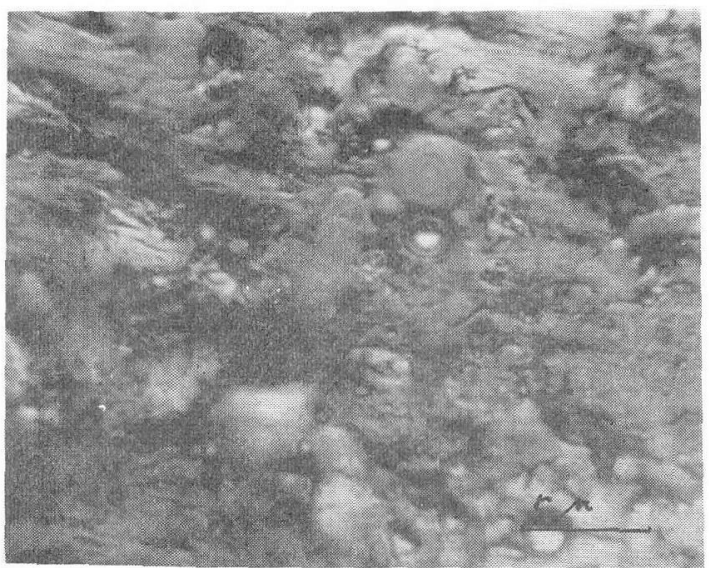

Photo 10 A Distribution of multi-Ringed Bodies of coal pitch coke under a microscope
く多重環の存在はない。その組織は石炭ピッチコークス と比較して, 流動模椂が極めて屈曲性に富むことが (a) で代表され，粒子の発達のよさが各写真からうかがわれ る。このようなコークス間の大きな差は, 原料と製法に よることと推定されるが, 今後さらに検討を要する問題 である。B 銘柄に環の存在が認められない理由は, 石沛 コークスを使用したためと推定され，素地の結晶粒度か 他銘柄と異る点からもこれが裹付けられている。

\section{4. 考察}

ピッチコークス系ブラシの多重環樍造を明らかにする ために電子顕微鏡観察を行なったが，より構造を明らか にするためには倍率の引上げが必要であり，これに伴な い研磨方法の改善やシャドウィングの工夫も必要である

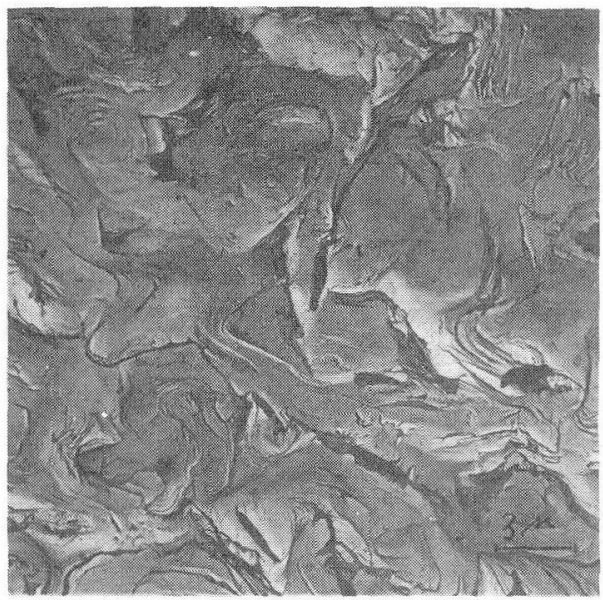

(a)

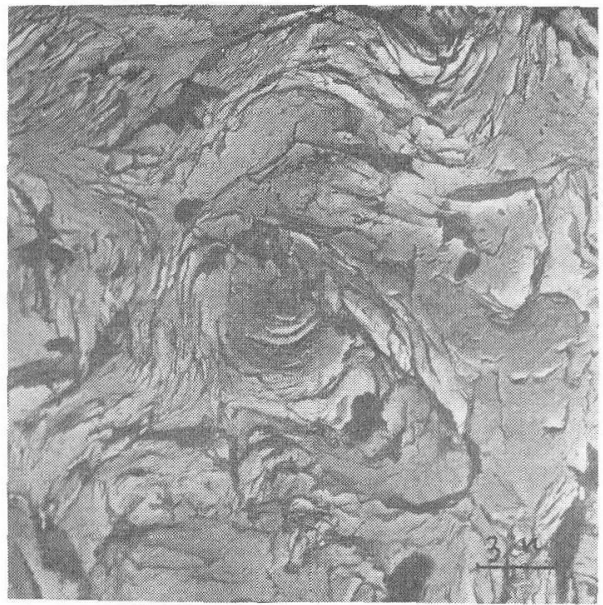

(b)

Photo 11 Micro-structuses of G. L. coke 


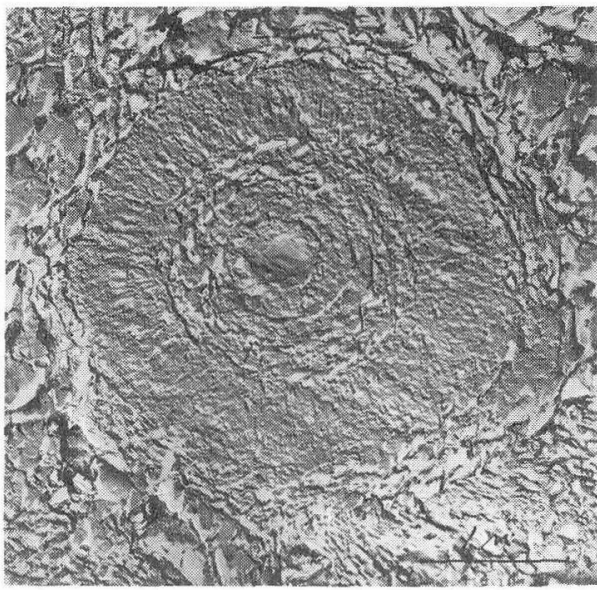

Photo 12 A Microstructure of multiringed body

直接倍率を 7,000 倍に引上げた例をPhoto 12 にあげ たが，求心方位環と円周方位環の構造がいくぶんはっき りしてきたがまだ不充分である。

多重環の特性については電気抵抗が高いと推定を下し たが，これは組織が微細である点から低黒鉛質炭素と考 えられる点と, 結晶方位が互に直交する環構造であるか らその境界層には結晶不整が多いと考えられる上に環の 脱落が起り易い点から接触抵抗が大きいと判断されたた めである。また阙性に富んで硬質と判断した理由は炭素 質に近い組織と破研工程を経てなお破研環が稀にしか観 測されない点からである。硬度が高いものはもろいと言 う一般通念があるので硬いが㓮性に富むと言う性質は一 見奇異である。しかし物性はすべて比較の表現であるか ら，鉄鋼中におけるソルバイト組織の鋼が㴊性に富んで 且比較的に硬度が高い例もある。硬質であるか否かの直 接的な测定は貒少硬度の测定によるほかないが，数 $\mu$ の 本体でしかも多重環から構成されているとするとその测 定も容易ではない。よほど試料に恵ぐまれないと測定不 能である。そこで電子影微鏡的視野の組織と硬度の関係 について広く検討寸れば，比較值としての硬度は推定で きると思う。今後さらに検討の必要がある。

多重環の特性を次のような（a）電気抵抗が高い， 硬質で環の脱落が起り易い，と考えた時にブラシ性能に 及汭す影響について考察してみよう。

すり接触時の真の接触面積は小さく, その数も少ない 上に，通電点の数は皮膜状態にもよるが一般に何重負荷 点の数より少ないことが知られている。また荷重負荷点 の総面積を $A_{b}$, 硬度を $U$, 接触圧力を $P$ とすると, 三 者の関係は $P=H A_{b}$ であると Holm ${ }^{(6)}$ により与えられ ている。したがって硬度と荷重負荷点面積は反比例の関
係にある。また摩耗における一般通念から組織中の硬成 分の摩耗量は素地よりも小さいから，硬成分の存在はこ の個所での接触確率が高くなることを意味している。こ のさい接触面積は上式により减少するばかりでなく，接 触点の数も硬成分の变形率が小さい理由から減少する方 向にむかう。多重環の役割は特性 (b)によって硬成分の 仕事を演ずることになる。さらに通電点はこれらの接触 点の中から選択されることになるが，このさい多重環は 特性（a）から通電点となる確率は小さい。したがって通 電点の数はさらに減少するので, 通電個所での電流集中 が過度になることは避けられない。この場合ブラシ性能 の低下は明らかである。一方相手金属側の軟化や損傷も 発生する。さらに多重環の存在が多量であれば上記の偭 向が顕著になるので荷重点における平均応力は著増する。 しかもブラシは振動を伴なうものであるから両者の兼ね 合いから極端な局部応力集中を発生する可能性が多い。 この場合整流子側には各種の障害が発生する(Photo 4 はその一例 )。

また特性（b）の環の脱落性は, 破砕され難さと伴なっ て，脱落しても接触面間にある時間，形を保って存在する ために接触不良の原因となるほか，すべり摩摖形態をこ ろがり摩摖へと転化する。このような現象は摩摖变動増 加の原因になり整流悪化とつながるものである。

一方ピッチコークス系ブラシ使用の整流子面は, 使用 日数の経過と共に面の黑化を発生し易い。黒化現象はク ラフォイトの付着であるから，放置すると整流悪化につ ながるために除去する必要がある。この作用をブラシに もたせたものが研磨性である。しかし研磨性については これまで実体不明であるばかりでなく，測定法もない単 なる抽象的な概念に過ぎなかったように思われる。勿論 黒鉛化不良であったり厕分が多ければ研磨性が大きいと 言われているが，これらは異常ブラシに属することであ って，黒鉛化も良好であると言うピッチコークス系ブラ シで，整流子荒損や整流悪化がばらつきとして存在する ときの説明にはなり難い。多重環の存在が明らかになり その特性に対してもかなりの推定が成立つ現状において は，ばらつきや研磨性の問題をこれと関連させて考える ことは当然な成り行きである。現車試験結果と対応させ て 5 銘柄の特俨を述べると，A 銘柄は荒損の傾向がある ほか，異常摩耗を発生することがあり，B銘柄は整流子 の黑化傾向を持つほか, 摩耗量が多い傾向がある。C, $\mathrm{D}, \mathrm{E}$ の各銘柄は両者の中間型である。A銘柄は写真で も見られるように多重環が比較的大形であるばかりでな く，その量も多い。一方B銘柄には多重環がない。B銘 柄の黒化傾向は摩耗量が多いことと結びつき，研磨性不 足傾向はあらそえない。A 銘柄の整流不良や荒損を，多 
重環の量と特性に結びつければこれまで述べてきた点か ら明らかに理解できるし, 研磨性過多と呼ぶことが出来 る。また異常摩耗を発生し易い点も多重環と素地との結 合が平均状態より弱い場合には脱落摩耗形態が促進され る点から推測することができる。このさい整流悪化が促 進することも見逃がせない。

以上の点から多重環が研䄷性と関連があり, 少量且分 布が良好である場合には好結果を産む。一方全然ない場 合には研磨性不足から摩耗量を増加する。さらにまた多 重環の分布如何がばらつきの原因になることが指摘され る。これを広く言えば, 組織のばらつきが性能のばらつ きに対応していると言い得る。これまで物理特性面から のみばらつきが論ぜられていたが，その值は平均值であ るばかりでなく，すり接触本来の現象を突いていない点 があったと言える。この意味からブラシ組織の研究が必 要であるが，これも緒についた時点と言えるに過ぎない ので今後の研究がさらに必要である。

\section{5. 結 論}

ピッチコークス系ブラシ組織の電子顕微鏡観察を行な って, 次の結果を得た。

1）ピッチコークス系ブラシには径数 $\mu の$ 多重球殸体 があり，ときには複合型や連続型をとり $20 \mu$ 越えるも のもある。

2）球殼体は原料石炭ピッチがュークス化する流動過 程中で形成され，石油コ一クスには存在しない。

3）球殼体は黒鉛化度の低いものが多く, 緻密且硬質 で素地から脱落し易い上, 電気比抵抗が高い。
4）球殼体の量と分布はすり接触と多大な関係があり, 研磨性やばらつきの有力因子である。

$$
\text { 6. むすび }
$$

本研究遂行に当り試料の提供その他の御協力を得た日 本, 東海, 日立の各社に厚く御礼申上げます。

$$
\text { 文献 }
$$

(1) Holm, R. ; Eine Bestimmung der wirklichen Berükrungs-Fläche eines Bürstenkontaktes. Wiss. Veröff. Siemens-Werk, $17 / 4$ (1938) 43

(2) Rabinowicz, E. and D. Tabor ; Metallic Transfer between sliding Metals : An auto radiographic Study Proc. Roy. Soc., Lond. A $208(1951) \quad 455(60,151,217,217)$

(3) 国分 ; Microscopic Obse rvation on Sliding Surfaces of Carbon Brushes ; Symposium On Carbon, Tokyo July 1964

（4）国分；ブラシのすり特性測定法, 学振 117 委, $117-93-\mathrm{B}-1$

(5) Fulam, E. F., and R. H. Savage ; Carbon Film Formation and Commutator Brush Wear as revealed by the Flectron Microscope, J. Appl. Phys., 19 (1948) 654

(6) Holm, R.; Electric Contacts Handbook (1958) p. 35

$$
\text { ニュース }
$$

第8回国際炭素会議の発表論文

6 月 18 日から 23 日まで, アメリカのバファロー市で開催される第 8 回国際炭素会議に 発表申込みをされた論文数は合計 184 篇にのぼり，その国別内訳けは次記のとおりである。

記

フランス 25 , ドイッ 7 , イギリス 30 , 日本 18 , ソビエト 2 , 北アメリカ 91 ,
ベルギー 4 , エジプト 1 , インド 1 , スイス 2 , ポーランド 2 